\title{
EFFECT OF FEEDING MORINGA ON SUDANESE DESERT SHEEP PERFORMANCE
}

\author{
Sawsan, F. A. Salih., I. Bushara and Muna, M. M. Ahmed \\ ${ }^{1}$ Department of Animal Production. Faculty of Natural Resources and Environmental Studies \\ University of Kordofan El-Obied, Sudan \\ ${ }^{2}$ Institute of Environmental Studies, University of Khartoum, Sudan \\ bushara3030@yahoo.com
}

\begin{abstract}
The experiment was conducted on desert male sheep's to evaluate the effect feeding moringa on body weight gain, feed intake and body weight change. Twelve (12) rams of desert sheep aged 4-5 months and weighing $12.1 \mathrm{Kg}$ (11.7-12.4 Kg) were used in these experiments. The goats were divided randomly into three groups; each group (4 males) in complete randomized design. The results revealed that the group one which fed mixture of rang plants showed the heaviest body weight gain as $104.48 \mathrm{~g} /$ day compared with other feeds. The effect of feeds on body weight change and final gain, was significant $(\mathrm{P} \leq 0.001)$ with the mixture of range plants with moringa $(26.77 \pm 0.68 \mathrm{~kg})$ and mixture of range plants alone $(25.33 \pm 0.76 \mathrm{~kg})$ compared with moringa alone $(22.77 \pm 3.87 \mathrm{~kg})$.
\end{abstract}

Keywords: sheep, range plants, Moringa, body weight

\section{INTRODUCTION}

The rangelands are of importance to traditional livestock rising are confined to the semi-desert, low rainfall savannah, and the northern fringes of the high rainfall areas. In the semi- desert the plant cover is a mixture of grasses and herbaceous plants intermingled with Acacia trees and shrubs representing the main grazing areas for camel and sheep. Previous records showed that the range carrying capacity is not in balance with livestock feed requirements. There is gap between current rangeland production and the actual requirement. This gap amounts to 23.35 million tons of TDN. In such situations, the available grazing is not generally sufficient to meet the maintenance requirements of animals, at least for part of the year (Aregheore, 2002).

The livestock sector plays a significant economic role in most developing countries, and is essential for the food security of populations. The pastoralists in Khartoum State raising cattle, goats and sheep move all the year searching for water and feed for their animal in the rangelands, their animals suffering from lack of feed. The productivity of farm animals in most tropical countries is generally low, mainly due to poor quality and inadequacy of available feeds.

Moreover, conventional feed resources (grains, cereals, legumes, etc.) for animal production are scarce and highly expensive in many parts of the world. Thus searching for alternative unconventional feed sources that may have valuable components of animal diets is indispensable (Szumacher-Strabel et al., 2011; Zhou et al., 2012). The use of tree parts as alternative feed resources for ruminant livestock is becoming increasingly important in many parts of the tropics and sub-tropics (Silanikove, 2000; Melesse et al., 2009). In fact, trees and shrubs are increasingly recognized as important components of animal feeding, particularly as suppliers of protein and especially in harsh environmental conditions. 
Trees are used for a variety of purposes in both cropped lands and in livestock grazing systems. Traditionally, farmers on dry land of Africa have developed a wide range of agroforestry and soil conservation strategies to adapt their crops and livestock production system to the marginal condition (Mbwambo, 2004). The challenges in using forage as source of feed for animals are estimating its availability and intake and determining whether or not the forage can supply adequate nutrients for maintenance, growth, reproduction and lactation. Animal owners traditionally use tree leaves, bushes and creepers for feeding animals. Besides the leaves, they make extensive use of the flowers, pods and seeds of some trees have always played a significant role in feeding domestic animals as feed supplements.

Present knowledge on the potential value of fodder trees and shrubs indicates that together with their diversity, these feed resources are extremely useful for feeding domestic ruminants. The demonstrable benefits are improved performance of animals and reduced cost of feeding (Devendra, 1992 and Aregheore, 2002). Moringa (Moringa oleifera) trees are multi-purpose trees of economic importance with several industrial and feeding values (Babker and Abdalbagi, 2015). The traditional feeding systems, particularly in tribal areas, make maximum use of local resources like crop residues, tree leaves, pods, seeds, etc. (Pradhan et al., 1991). Improve the animal production and reduce the animal mortality. The objective of this study is to evaluate the effect of feeding Moringa oleifeira and mixture of range plants on body weight gain, and weight changes of Sudanese Desert sheep.

\section{MATERIALS AND METHODS}

This study were conducted in Omdurman area (Umbada locality, longitudes $15.7^{\circ} \mathrm{N}$, Latitudes $34.4^{\circ} \mathrm{E}$ and altitudes $1402 \mathrm{~m}$ above sea levels) Khartoum state.The annual rain fall is $200-400 \mathrm{~mm}$, and the temperature is range $17-20^{\circ} \mathrm{C}$ in the winter and $30-48^{\circ} \mathrm{C}$ in the summer. The pastoralists in the area raise cattle, goats and sheep (7.7 million heads), moving all the year searching for ranges, fodder and water. The areas is occupied by some sedentary tribes with ownership of land and raising small number of animals cattle utilizing the nearby annual low quality pastures and browse trees.

\section{EXPERIMENTAL ANIMAL'S MANAGEMENT AND DIETS}

Twelve (12) rams of Sudanese sheep rams were used in this experiment, with ages 9-12 months and weights ranging from $17-21 \mathrm{~kg}$. All animals were treated with the necessary medication against endo-and ecto-parasites (AGVET, USA $1.0 \mathrm{ml} / 50 \mathrm{~kg}$ body weight subcutaneously Ivomec super drench) and vaccinated against Anthrax and Hemorrhagic Septicemia. The animals were ear tagged, weighted and divided into three groups and allocated to three groups, each group with 4 rams ; group one, is mixture of range plants (MRP), group two is moringa pods stem and leave (M) and group three is mixture of Moringa leaves and range plants (M+MRP) as $50 \%$ to $50 \%$. Feeds were offered to rams at ad libitum. Each group consistent of six rams and fed individual and was kept in separate enclosures constructed from iron bars and wire, and equipped with water troughs. They were gradually introduced to the new feeds for a preliminary period of 7 days. Live weight each animal were recorded at the start of experiment, then every two weeks until the end of the experiment in three months, using spring balance, the animals were weighed in the morning.

\section{STATISTICAL ANALYSIS}

The data were statistically analyzed according to complete block randomized design. Multiple range tests were used to compare the means using Statistical Package for the Social Sciences, software package (SPSS, 1999).

Volume 2 


\section{RESULTS}

\section{Effect of Moringa on body weight gain and conversion feed ratio}

Sheep fed plants under study showed increase in body weight. The mean gain of the body as in table 4.8 was 4.7 Kg. for the group fed range species, 3.3Kg. for the group fed moringa and 7.1 for the one fed (M+R) The FCR for the group fed $(\mathrm{M}+\mathrm{R})$ was 0.082 , followed by the group fed range species 0.044 and the one fed the moringa was 0.039 . There were significant increases obtained when feeding a mixture of range species $(\mathrm{P} \leq 0.05)$ and when feeding the mixture plus moringa $(\mathrm{P} \leq 0.05)$ as shown in Table (1) Fig (1).

Table 1. Body weight gain $(\mathrm{kg})$ and Food conversion ratio for sheep fed plants

\begin{tabular}{|l|c|c|c|}
\hline Groups of animals & Body weight gain (kg) & Mean feed intake(g) & FCR* \\
\hline Group one (MRP) & 4.7 & 104.48 & 0.044 \\
\hline Group two (M) & 3.3 & 84.14 & 0.082 \\
\hline Group three (MRP+M) & 7.1 & 86.96 & 0.039 \\
\hline *FCR= feed conversion ratio & \multicolumn{3}{|l}{} \\
\hline
\end{tabular}

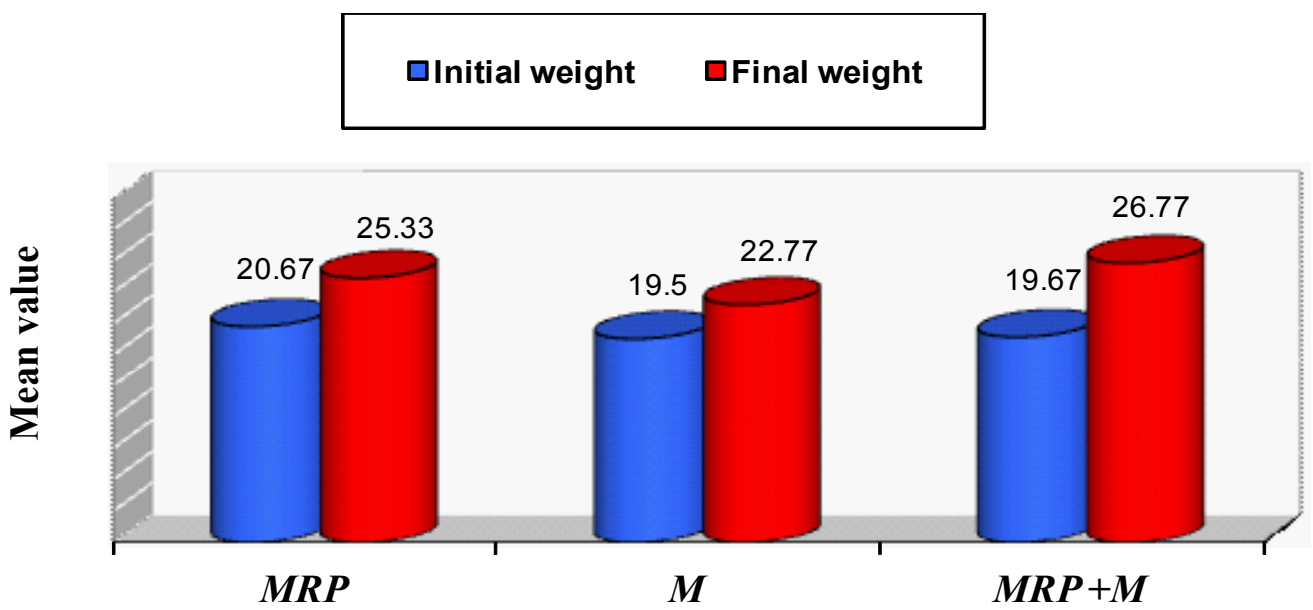

Fig1. Initial and final body weights ( $\mathrm{kg}$ ) for sheep fed plants under study

\section{Effect of Moringa on final body weight and growth rate}

The effect of feeding of different feeds on body weight gain and growth were summarized in Table (2). Feeding mixture of range plant with Moringa showed significant $(\mathrm{P} \leq 0.001)$ effect. Also feeding mixture of range land plants significantly $(\mathrm{P} \leq 0.005)$ affect growth rate of the rams better than feeding moringa alone.

Table2. Initial and final body weights $(\mathrm{kg})$ for sheep fed plants under study

\begin{tabular}{|l|l|l|l|l|}
\hline Groups of animals & Initial weight & \multicolumn{1}{|c|}{ Final weight } & t value & p value \\
\hline Group one (MRP) & $20.67 \pm 0.58$ & $25.33 \pm 0.76$ & -6.424 & $0.023^{*}$ \\
\hline Group two (M) & $19.50 \pm 2.18$ & $22.77 \pm 3.87$ & -3.287 & $0.081 \mathrm{NS}$ \\
\hline Group three (MRP+M) & $19.67 \pm 1.53$ & $26.77 \pm 0.68$ & -14.393 & $0.005^{* *}$ \\
\hline \multicolumn{2}{|l}{ NS = not significant; ${ }^{*}=$ significant at $\mathrm{P} \leq 0.05=; * *$ significant at $\mathrm{P}<0.01$} \\
\hline
\end{tabular}




\section{DISCUTION}

and shrubs are increasingly recognized as important components of animal feeding, particularly as suppliers of protein and especially in harsh environmental conditions. (Aregheore, 2002). Significant gains in animals' weights were detected when fed a mixture of range plants, but better gains were obtained when moringa shoots were added to the mixture. These were also detected when comparing the feed conversion ratio. Similarly the potential for agroforestry to supply animals with high quality feed has been recognized by many authors (Makkar and Becker, 1997; Fuglie, 2001; Mauricio et al., 2008). It was also shown that by planting a leguminous tree species in between rows of the grass, the nutritive value of the grass can be increased, improving livestock production (Harsh et al, 2003). A study in Fiji reports significant weight gain over traditional fodder when $50 \%$ of fodder contained moringa. Animals given fodder with $80 \%$ moringa in the Fijian study showed lower weight gain than animals on 50\% moringa fodder (Aregheore, 2002). The traditional feeding systems, particularly in tribal areas, make maximum use of local resources like crop residues, tree leaves, pods, seeds, etc. (Pradhan et al., 1991). Many studies led to the development of methods of assessing the nutritive value of feeds and standardizing the feeding of animals according to their chemical composition. A study on the grazing behavior of goats; diet selection, nutritive value, digestibility of range plant and body gained at flowering and seed setting stage, showed that the flowering stage was the best for goat in term of feed intake, dry matter digestibility and body weight gain (Abdel Moniem et al. 2013). Also in vitro gas production of Trifolium angustifolium hay showed that wild Trifolium angustifolium harvested even at the seeding stage, offered considerable potential as medium quality forage for ruminant animals during the winter period (Ademk and Canbolat 2010). It has been stated that the leaves, shoots and twigs of legume/browse plants can help overcome the nutritional constraints of tropical grass species that are low in nutritive quality. (Mandal, 1997) and play an especially important role in improving dietary protein (Aregheore et al., 1998). Generally Moringa leaves are also a good protein source that is a convenient substitute of some meals (soybean and rapeseed) for ruminants, and they are able to improve the microbial protein synthesis in the rumen (Soliva et al., 2005).

\section{CONCLUSIONS}

It could be recommended that Moringa can help small and medium-scale farmers overcome shortages of good quality feeds and therefore sustain and improve their livestock productivity, and the Agroforestry can be adopted as strategic nutrition supplementation as many tree leaves, flowers and pods are identified as useful for improving milk production, milk fat, body condition and for the induction of estrus. In situations, where the available grazing is not generally sufficient to meet the maintenance requirements of animals, at least for part of the year, trees can alleviate the feed shortages or even fill up the feed gaps especially in the summer period when grassland growth is limited or dormant, due to unfavorable weather conditions.

\section{REFERENCES}

Abdel Moniem M.A. El hag A., I, Bushara., Eisa M.O. and Ishag I.A. 2013. Effect of plant maturity stage on digestibility and distance walked for diet selection by goat at north Kordofan State, Sudan. Global Journal of Animal Scientific Research, 1(1): 1-6.

Ademk k. and Canbolat O. 2010. Determination of nutritive value of wild narrow-leaved clover (Trifolium angustifolium) hay harvested at three maturity stages using chemical composition and in vitro gas production. Tropical Grasslands (2010) Volume 44, 128-133.

Aregheore E M, Makkar H P S and Becker K. 1998. Feed value of some browse plants from the Central Zone of Delta State, Nigeria. Tropical Science, 38:97-104.

Aregheore, E.M. 2002. Intake and digestibility of Moringa oleifera-batiki grass mixtures by growing goats. Small Ruminant Research 46:23-28.

Volume 2 
Babker E.A and Abdalbagi, Y.M. 2015. Effect of feeding different levels on Moringa Oleifera leaves on performance, haematological, biochemical and some physiological parameters of Sudan Nubian goats. Online Journal of Animal and Feed Research. Volume 5, Issue 2: 50-61.

Devendra , C. 1992. Nutritional potential of fodder trees and shrubs as protein sources in ruminant nutrition. Legume trees and other fodder trees as protein sources for livestock. Proceedings of the FAO Expert Consultation held at the Malaysian Agricultural Research and Development Institute (MARDI) in Kuala Lumpur, Malaysia.

Fuglie, L.J. 2001. The Miracle Tree: Moringa oleifera: Natural Nutrition for the Tropics, p: 172. The Miracle Tree: The Multiple Attributes of Moringa .

Harsh, LN, Khan HA, Bohra, M.D. and Tewari, J.C. 2003. Growth performance and gum production of Acacia Senegal in different landforms in hot arid zone of India. Journal of Non-timber Forest Products 10, 1-7.

Makkar, H., Becker, K. 1997. Nutrients and antiquality factors in different morphological parts of the Moringa oleifera tree. J. Agric. Sci. 128,311-332.

Mandal, L. 1997. Nutritive value of tree leaves of some tropical species for goats. Small Ruminant Research 24:95-105.

Mauricio, R., Sousa, L., Moreira, G., Reis, G. and Gonçalves, L.2008. Silvopastoral systems as a sustainable alternative to animal production in the tropics. In: O. Casteln, A.R. Bernués F.

Mbwambo, L. 2004. Status of Agroforestry in arid and semiarid areas of Tanzania. Paper presented at the ICRAF Dryland Agroforestry Workshop, 1-3 September 2004.

Melesse A, Bulang M and Kluth H. 2009. Evaluating the nutritive values and in vitro degradability characteristics of leaves, seeds and seedpods from M. stenopetala. J. Sci. Food Agr, 89: 281-287.

Silanikove N. 2000. The physiological basis of adaptation in goats in harsh environments. Small Ruminant Res., 35: 181-193.

Soliva C, Kreuzer M, Foidl N, Foidl G, Machmüller A and Hess H (2005). Feeding value of whole and extracted Moringa oleifera leaves for ruminants and their effects on ruminal fermentation in vitro. Animal Feed Science and Technology, 118: 47-62.

SPSS.1999. Statistical package for social sciences, Ver.10.0. Chicago: SPSS Inc.,

Szumacher-Strabel M, Zmora P, Roj E, Stochmal A, Pers-Kamczyc E, Urbańczyk A, Oleszek W, Lechniak D, Cieślak A. 2011. The potential of the wild dog rose (Rosa canina) to mitigate in vitro rumen methane production. J. Anim. Feed Sci., 20: 285-299.

Pradhan, P.K., Jape A.S. and Rangnekar. 1991. Traditional livestock management \& feeding systems in tribal ares of Gujarat and Rajasthan. Paper presented at International Workshop on Feeding of Ruminants on Fibrous Crop Residues. National Dairy Research Institutes, Karnal, India.

Zhou B, Meng QX, Ren LP, Shi FH, Wei Z and Zhou ZM. 2012. Evaluation of chemical composition in situ degradability and in vitro gas production of ensiled and sun-dried mulberry pomace. J. Anim. Feed Sci., 21: 188-197.

Citation: Sawsan, F. A. Salih., I. Bushara and Muna, M. M. Ahmed, "Effect of feeding Moringa on Sudanese desert sheep performance". American Research Journal of Agriculture, Volume 3, 2017; pp:1-5

Copyright (c) 2017 Sawsan, F. A. Salih., I. Bushara and Muna, M. M. Ahmed, This is an open access article distributed under the Creative Commons Attribution License, which permits unrestricted use, distribution, and reproduction in any medium, provided the original work is properly cited. 